\title{
A (RE)CONSTRUÇÃO DE MITOS Sobre a (In)Sustentabilidade Do(No) Espaço Urbano
}

\author{
MARÍLIA STEINBERGER
}

R E S U M O O trabalho parte de uma leitura do conhecimento produzido sobre meio ambiente, no âmbito dos Encontros da Anpur dos anos 90, para discutir a emergência do meio ambiente urbano como área de investigação que constrói e reconstrói mitos sobre a sustentabilidade ou insustentabilidade do espaço urbano. Para tanto, numa primeira seção, são analisados documentos que constituem o marco institucional da área e realiza-se um breve resgate de marcos teórico-conceituais estabelecidos em algumas disciplinas, sugerindo que eles devem ser desconstruidos, para que o meio ambiente urbano seja apreendido com um olhar baseado em uma racionalidade não-instrumental. Na seção seguinte, são discutidos os focos socialhistórico e político-espacial de três pares de noçôes/conceitos: ambientelmeio ambiente, desenvolvimento sustentável/sustentabilidade e território/urbanização, para se chegar a um entendimento sobre sustentabilidade urbana. Tais focos orientam as questôes centrais que perpassam a área: qualidade ambiental urbana, instrumentos de gestão ambiental e conflito de interesses entre os atores. À guisa de conclusão, mostra-se que, embora a maioria dos discursos sobre o meio ambiente urbano considere o espaço urbano como insustentável, há caminhos que apontam para uma definição da área.

P A L A V R A S - C H A V E Meio ambiente; sustentabilidade; espaço urbano.

\section{INTRODUÇÃO}

Em 1999, o Encontro Nacional da Anpur definiu "Desenvolvimento Urbano Sustentável: que Qualidade e para Quem?” como uma das áreas temáticas, no âmbito da qual foram apresentados dezesseis trabalhos. De fato, o tema meio ambiente já vinha sendo discutido nos encontros anteriores: em 1993, numa subseção intitulada "O Nexo Meio Ambiente - Planejamento Territorial em Questão”, contou com quatro trabalhos; em 1995, na seção "Urbanização, Desenvolvimento Regional e Meio Ambiente", esse número passou para oito; e em 1997, englobado no subtema "Meio Ambiente, Saneamento e Impactos de Grandes Projetos", atingiu onze. Diante desse quadro, é digno de registro o crescente interesse dos planejadores/pesquisadores urbanos e regionais por esse tema ao longo dos anos 90 .

Considerando que a idéia aqui é apontar rumos, decidiu-se analisar todos os textos discutidos nos encontros citados, não para elaborar um balanço, mas para descobrir como vem ocorrendo o processo de produção do conhecimento sobre o tema no Brasil, supondo que a Anpur é um fórum representativo do mesmo.

$\mathrm{Na}$ leitura dos trabalhos, observou-se que esse processo nem obedeceu a uma linha de pensamento única nem a um roteiro lógico capaz de indicar que os pesquisadores estavam indo em direção a um compromisso com posturas fechadas. A produção foi errática, o que, longe de causar preocupação, caracteriza uma área de investigação nova, dinâmica e não consolidada, mas em busca de uma identidade. 
Portanto, não se pode dizer que as discussōes sobre a insustentabilidade da cidade estejam ultrapassadas, porque alguns discursos mais recentes proclamam sua sustentabilidade. Embora essa afirmação demonstre a expectativa de um grupo de estudiosos, ela não reflete o estado da arte do conhecimento produzido. Parece mais adequado dizer que há uma coexistência conflituosa de abordagens.

Admitir essa coexistência significa reconhecer que os pesquisadores vêm trilhando dois caminhos para discutir a sustentabilidade urbana. Há os que partem da insustentabilidade da cidade para propor soluçôes a fim de torná-la sustentável. Ao mesmo tempo, há os defensores da sustentabilidade da cidade de per si, olhada com a lente positiva que privilegia os distintos significados do estar aglomerado. No embate entre esses dois caminhos, constata-se um ponto de contato importante: falar de (in)sustentabilidade urbana não quer dizer falar só de cidade. De fato, boa parte dos trabalhos elaborados envolve territórios urbanos diferenciados.

Com base nessa constatação, aqui se tomou uma segunda decisão: adotar como referência o espaço urbano, pois esse pode comportar territórios maiores ou menores do que os limites da cidade. Maiores, quando o espaço urbano se espraia e se confunde com o regional ou com o rural e adquire contornos geográfico-administrativos, como o de uma bacia hidrográfica, uma região metropolitana ou um município; menores, quando o espaço urbano se relaciona a um bairro, uma comunidade, um assentamento habitacional ou uma "tribo". Por essa razão, sugere-se que o "mote" da perseguida sustentabilidade não seja a cidade, mas sim o espaço urbano, entendido como resultante desse mosaico de territórios que está em constante mutação. Assim, não existe o ser sustentável mas o estar sustentável, tão-somente como um estado temporário de determinados territórios que contêm e estão contidos em um meio ambiente predominantemente urbano.

Face a isso, o título escolhido para este artigo tem o intuito de ressaltar que o objeto da referida produção de conhecimento é o meio ambiente urbano, o qual vem sendo esboçado a partir desses vários tipos de territórios analíticos, onde é possível observar a construção e a reconstrução de mitos sobre a (in)sustentabilidade no(do) espaço urbano, como será visto adiante.

Isso não quer dizer deixar de lado a expressão "desenvolvimento urbano sustentável". Ao contrário, significa compreender que ela é composta por três elementos-chave: desenvolvimento como objetivo macro, finalístico e permanente; sustentável como objetivo meio, adjetivo de um estado temporário, e espaço urbano (conteúdo e continente do meio ambiente) como objeto de gestão.

Nesse sentido, presume-se que existe meio ambiente no espaço urbano e, portanto,

1 Essa área está inserida em um processo de produção do conhecimento mais amplo, que não se restringe ao Brasil, pois os autores consultados se valem tanto da literatura nacional como internacional. o meio ambiente urbano é um objeto de uma complexidade tal que comporta uma área de investigação. ${ }^{1}$ Como suporte a essa idéia, serão extraídos recortes dos textos dos vários autores consultados para buscar os argumentos da identidade da área e, assim, chegar a uma definição dela, calcada em uma racionalidade própria, conduzida por um novo olhar. Esse olhar, que ora se propõe, foi ensejado pela leitura dos trabalhos, mas não toma nenhum deles no seu todo.

Com esse propósito, primeiramente, serão apresentados os marcos que embasam a área para, em seguida, identificar as questóes e propostas que a perpassam e, à guisa de conclusão, mostrar alguns de seus discursos próprios. Três indagações nortearão o pano de fundo da discussão:

- a partir de quando e em que bases o meio ambiente urbano surgiu como uma área de investigação? 
- há discursos específicos sobre o meio ambiente urbano ou uma mera transposição e adaptação de discursos de disciplinas que têm dado suporte às áreas de meio ambiente e de planejamento urbano?

- está sendo repensado o espaço urbano por intermédio do meio ambiente?

\section{O MEIO AMBIENTE URBANO COMO UMA ÁREA DE INVESTIGAÇÃO}

Para mostrar que o meio ambiente urbano é, de fato, uma área de investigação, serão utilizados dois enfoques. O primeiro refere-se à identificação de um marco institucional, supondo que, de certa maneira, ele equivale a um reconhecimento oficial da existência da área. O segundo respalda-se no debate em torno da desconstrução de mitos construídos em marcos teórico-conceituais estabelecidos, passo inicial e revelador da emergência de uma nova área.

\section{A IDENTIFICAÇÃO DE UM MARCO INSTITUCIONAL}

$\mathrm{Na}$ Conferência de Estocolmo, em 1972, a delegação brasileira defendeu a tese de que a proteção ao meio ambiente era um objetivo secundário para os países em via de desenvolvimento, pois entrava em conflito com o crescimento econômico. Essa tese foi derrotada, razão pela qual consta que a criação da Secretaria Especial de Meio Ambiente, em 1973, obedeceu a uma "necessidade diplomática de corrigir a imagem negativa do Brasil a nível internacional" (Manosowski,1989, apud Sá et al.,1995:278).

Nesse mesmo ano, foi cunhado o termo "ecodesenvolvimento", ao se propor uma atuação voltada para um uso mais cuidadoso dos recursos naturais nas áreas rurais do Terceiro Mundo. Com a Declaração de Cocoyoc, assinada no México, em 1974, essa mesma preocupação se estendeu às cidades.

Daí por diante, várias decisões relativas ao meio ambiente foram tomadas no Brasil. Algumas delas, ligadas ao espaço urbano, como a edição do capítulo de Política Urbana e Meio Ambiente no II PND, em 1974, e a Lei de Zoneamento Industrial em Áreas Críticas, de 1979 (dirigida, principalmente, às regiōes metropolitanas). Entretanto, tais decisões ainda não representavam uma ampla conscientização quanto à importância do meio ambiente urbano. Eram fatos isolados.

Há quem considere a Constituição de 1988 o primeiro marco do surgimento do meio ambiente urbano como uma área de investigação, no Brasil. Isso porque o seu texto contém duas inovações relacionadas à área: a inclusão da função social da propriedade entre os princípios gerais da ordem econômica, e a possibilidade de qualquer cidadáo fiscalizar bens ambientais, históricos e culturais. Entretanto, embora admitindo o avanço dessas inserçōes constitucionais, outros autores advogam que a Carta Magna é vaga quanto às questôes ambientais urbanas, pois apenas concede aos municípios, aos Estados e à União o poder de legislar, concorrentemente, sobre o assunto (Marques da Silva,1999:4).

$\mathrm{Na}$ verdade, a área de meio ambiente urbano ganhou força, no Brasil e no mundo, a partir do Fórum Global das ONGs, que se realizou paralelamente à Conferência das Nações Unidas para o Meio Ambiente e Desenvolvimento (Eco 92), quando se explicitou que a questão ambiental era também uma questão urbana. Numa conferência em que a tônica central foram as questôes ambientais de cunho global, a preocupação com o meio 
$2 \mathrm{Em}$ continuidade às discussões que já vinham ocorrendo desde o fim dos anos 70 , sobre a então denominada Lei de Desenvolvimento Urbano.

3 Outras diretrizes também relacionadas ao meio ambiente urbano são: ordenação e controle do uso do solo, de forma a evitar a poluição e a degradação ambiental; adoção de padrões de produção e consumo de bens e serviços e de expansão urbana compatíveis com os limites da sustentabilidade ambiental, social e econômica do município e do território sob sua área de influência; proteção, preservação e recuperação do meio ambiente natural e construído, e regularização fundiária e urbanização de áreas ocupadas por população de baixa renda, mediante o estabelecimento de normas especiais de urbanização, uso e ocupação do solo e edificação, consideradas a situação socioeconômica da população e as normas ambientais.

4 Além disso, nos demais instrumentos (Parcelamento, Direito de Preempção, Operações Urbanas Consorciadas, Transferência do Direito de Construir e Estudo de Impacto de Vizinhança), há uma clara referência à sua aplicação para manter ou criar áreas de interesse ambiental e para reforçar 0 respeito à legislação ambiental vigente. Vale ressaltar, ainda, que a obrigatoriedade de elaborar planos diretores foi estendida para municípios inseridos na área de influência de empreendimentos e atividades com significativo impacto ambiental regional ou nacional. ambiente urbano foi introduzida pelo Fórum Brasileiro de Reforma Urbana e expressada, formalmente, no "Tratado sobre a questão urbana: por cidades, vilas e povoados, justos, democráticos e sustentáveis" (1994).

Os signatários desse Tratado buscavam contribuir para o avanço dos movimentos sociais e para a construção de uma vida digna nas cidades por meio da ampliação dos direitos de seus habitantes, mudança na gestão e na qualidade da vida urbana; construção de um meio ambiente a ser desfrutado pelas atuais e futuras gerações. Definiam que "o urbano se redimensiona como centro das atividades humanas e como ponto focal de processos políticos e econômicos. As cidades tornam-se centros de gestão e de acumulação do capital, organizados em escala planetária, núcleos de comando de uma vasta rede que integra o urbano e o rural. Essa dimensão territorial expressa uma crescente integração das problemáticas rurais, urbanas e meio ambientais" (HIC/Fococ, 1992:87).

Essa postura foi inovadora, dado que o Relatório do Brasil para a Eco-92 havia adotado uma outra direção ao relacionar duas causas da crise ambiental com o modelo de desenvolvimento: a pobreza e o mau uso da riqueza. Nesse contexto, o meio ambiente urbano foi inserido a partir da identificação de problemas: "Por um lado a pobreza das cidades ... que se confunde com a degradação ambiental. Por outro lado ... os problemas causados pela concentração das atividades econômicas ... nas localidades urbanas." (Cima, 1991:60).

Também no início da década de 1990, foi proposto, no âmbito do Congresso Nacional, um projeto de lei conhecido como Estatuto da Cidade. ${ }^{2}$ Embora ainda não transformado em lei, sua tramitação encontra-se em estágio avançado, uma vez que não há dúvidas sobre a importância de sua finalidade: "Fixar parâmetros para a aplicação do capítulo da política urbana da Constituição Federal, definindo princípios e objetivos, diretrizes de ação e instrumentos de gestão urbana a serem utilizados, principalmente, pelo Poder Público Municipal" (Relatório do PL 5788/90 e seus apensos).

No que tange ao meio ambiente urbano, acompanhando a crescente importância que a área foi ganhando no decorrer da década, recentemente foram introduzidas, no Projeto do Estatuto, algumas orientações relevantes nos capítulos que tratam das diretrizes da política urbana e seus instrumentos. Com relação às diretrizes, cumpre destacar:

- garantia do direito a cidades sustentáveis, entendido como direito à terra urbana, à moradia, ao saneamento ambiental, à infra-estrutura urbana, ao transporte e serviços públicos, ao trabalho e ao lazer, para as presentes e futuras geraçóes;

- planejamento do desenvolvimento das cidades, da distribuição espacial da população e das atividades econômicas do município e do território sob sua área de influência, de modo a evitar e corrigir as distorçôes do crescimento urbano e seus efeitos negativos sobre o meio ambiente; $\mathrm{e}$

- audiência do Poder Público municipal e da população interessada nos processos de implantação de empreendimentos ou atividades com efeitos potencialmente negativos sobre o meio ambiente natural ou construído. ${ }^{3}$

Entre os instrumentos, dois são especificamente dirigidos ao meio ambiente urbano, a saber, o Zoneamento Ambiental e o Estudo Prévio de Impacto Ambiental. ${ }^{4}$

Por fim, o documento "Cidades Sustentáveis da Agenda 21 Brasileira" (MMA/PNUd, 1999) pode ser considerado como a mais recente contribuição para se construir um marco institucional da área de meio ambiente urbano. Seu objetivo é oferecer propostas para introduzir a dimensão ambiental nas políticas urbanas vigentes ou que venham a ser adotadas. Dentre as premissas que o nortearam, merece destaque a denominada crescer sem 
destruir, por traduzir que o desenvolvimento sustentável das cidades implica, ao mesmo tempo, o crescimento dos fatores positivos da sustentabilidade urbana e a diminuição dos impactos ambientais, sociais e econômicos indesejáveis no espaço urbano. O documento parte de diagnósticos setoriais a fim de identificar os pontos de estrangulamento mais críticos para o desenvolvimento urbano sustentável. Com base neles, conclui que a cidade brasileira do século XXI poderá ser o palco de uma vida urbana enriquecida, desde que se operem as necessárias transformações dos padrões insustentáveis de produção e consumo que resultam na degradação dos recursos naturais e econômicos do País, afetando as condições de vida da população nas cidades. ${ }^{5}$

Além desses documentos, Rodrigues (1998) lembra que os trabalhos apresentados nas conferências nacionais e internacionais preparatórias para o Habitat II (Istambul, 1997), embora centrados na habitação, sugeriam um (re)pensar sobre o meio ambiente urbano, não como mera retórica, mas em torno de questôes concretas, tais como a qualidade de vida, a infra-estrutura e os equipamentos de consumo coletivo e a cidadania urbana.

Esse conjunto de documentos compõe o marco de referência institucional da área de meio ambiente urbano no Brasil, uma vez que significa uma oficialização da sua importância, por parte de entidades governamentais e não-governamentais brasileiras e internacionais.

Sobre o seu conteúdo, é preciso ressaltar que o corte analítico adotado em praticamente todos eles faz aflorar o principal ponto de conflito na área: a discussão entre meio ambiente natural e meio ambiente urbano. Há uma convergência de posicionamentos sobre a insustentabilidade do espaço urbano, calcado em diagnósticos que identificam problemas e pontos de estrangulamento a serem superados na busca da sustentabilidade.

\section{A Desconstrução de Mitos em Marcos Teórico-Conceituais Estabelecidos}

Como discutir se há sustentabilidade do meio ambiente gerado em um espaço, o urbano, que vem sendo considerado insustentável? Essa pergunta carrega uma contradição enganosa, ao colocar em oposição meio ambiente e urbano, pois considera o meio ambiente apenas como natural. Para responder a ela, é preciso desconstruir os mitos construídos no seio das principais disciplinas, que não só deram origem a essa falsa oposição, como também, paradoxalmente, à própria existência da área, a saber: Ecologia, Geografia, Sociologia, Economia e Urbanismo.

$\mathrm{Da}$ Ecologia vieram as teorias biocêntricas que surgiram como resposta à idéia de plasticidade na natureza, cujas bases conceituais, fundadas na razão verdadeira e universal do Iluminismo no século XVIII, tinham como certa a constante reconstrução da relação entre o homem e seu ambiente natural (Teixeira \& Bessa,1997). Ao negar a complexidade da natureza e admitir o homem como seu senhor absoluto, essa premissa transformou-se no pilar das teorias antropocêntricas. Veio também o conceito de capacidade de suporte dos recursos naturais para mostrar os limites da natureza que não devem ser extrapolados pelas atividades antrópicas. Vieram também as transposiçōes da teoria de sistemas em direção ao equilíbrio dos ecossistemas.

$\mathrm{Da}$ Geografia vieram três correntes de pensamento que são marcos obrigatórios para os estudiosos do meio ambiente, uma vez que seu ideário ainda faz parte de várias teorias contemporâneas. A primeira estava associada ao determinismo ambiental do final do século XIX e serviu de base para a definição de região natural. Em contraposição a essa
5 Para se atingir tal anseio, definem-se quatro estratégias prioritárias: aperfeiçoar a regulação do uso e ocupação do solo urbano; promover o desenvolvimento institucional e o fortalecimento da capacidade de planejamento e gestão democrática da cidade; promover mudanças nos padrões de produção e consumo da cidade, reduzindo custos $e$ desperdícios e fomentando o desenvolvimento de tecnologias urbanas sustentáveis, e estimular a aplicação de instrumentos econômicos no gerenciamento dos re cursos naturais visando à sustentabilidade urbana. 
perspectiva, na década de 1920 nasceu a visão possibilista, que não focalizava a natureza como determinante do comportamento humano, mas como fornecedora de possibilidades para o homem modificá-la. Preconizava que o homem, com sua cultura, criava uma paisagem e um gênero de vida peculiares em cada porção do território, dotando-a de personalidade. Assim surgiu o conceito de região geográfica ou região-paisagem (Gomes,1995). Outras correntes se sucederam, como a da Geografia crítica, que se apropriou dos ensinamentos marxistas sobre a natureza.

Da Sociologia veio a linha de pesquisa desenvolvida pela Escola de Chicago, principalmente no período de 1915 a 1940. Embora iniciada em 1902, com base na obra de Simmel que comparava a cidade a um organismo vivo, foi nesse intervalo que se produziram as principais contribuiçôes: a de Park, que considerava a cidade como obra da natureza humana e como habitat natural da sociedade civilizada; a de Wirth, que via o urbanismo como um modo de vida baseado numa ordem ecológica; e a de Wolman, que discutia as necessidades metabólicas das cidades.

$\mathrm{Da}$ Economia vieram teorias que tratavam a natureza como um recurso a ser explorado, como um fator ou meio de produção para gerar crescimento independentemente do tipo de uso que se fizesse dos recursos naturais, na certeza de que a tecnologia seria a grande saída. A natureza não apresentava custos. Existia para ser dominada e valorizada. Isso levou alguns críticos a se referirem à economia de rapina ou economia destrutiva. Imperava um modelo de desenvolvimento baseado na exploração ilimitada dos recursos naturais que, ao mesmo tempo, privilegiava a questionável idéia de que "uma diminuição da percentagem de população do setor primário deve ser considerada como um sinal de desenvolvimento econômico viável e permanente" (Alier \& Schlupmann, 1991:307). Em contrapartida, no início da década de 1970 alguns estudiosos propunham manter taxas elevadas de crescimento para financiar políticas ambientais, enquanto outros propunham a redução do crescimento, e até mesmo o crescimento zero. Também veio da Economia a conhecida visão castastrofista da escassez de Malthus, que previa um desequilíbrio entre o crescimento da população e a produção de alimentos, e foi resgatada nos últimos anos pela corrente do neomalthusianismo.

Do Urbanismo veio o movimento modernista do século XX, que buscava estabelecer uma nova relação entre arquitetura e o meio ambiente, e entre a cidade e a natureza, mas não logrou êxito, pois prevaleceu a estética da arquitetura moderna que, em geral, conduziu a uma dissociação entre edificação e natureza. Arquitetos e urbanistas dessa corrente dedicaram pouco tempo às questôes ambientais e à paisagem natural (Marques da Silva, 1999).

Todos os aportes teóricos citados, independentemente da disciplina a que estejam ligados, têm como pano de fundo a discussão das formas de apropriação da natureza pelo homem, em torno da qual foram sendo construídos mitos como: os limites da natureza; o equilíbrio ecossistêmico; a capacidade de o homem modelar a natureza; a tecnologia como regeneradora da degradação da natureza e solução da escassez; e a racionalidade do modernismo. Aqui, sugere-se que tais mitos precisam ser desconstruídos, porque são os responsáveis por gerar a oposição entre meio ambiente e urbano e, assim, "engessar" o espaço urbano à idéia de uma insustentabilidade permanente. Essa idéia se baseia na premissa de que o homem urbano, ao desrespeitar os limites da natureza, sempre cria um espaço urbano desequilibrado, pois as soluçôes tecnológicas e modernistas não dão conta de reverter esse quadro ou o fazem de maneira paliativa.

A desconstrução inicia-se tomando emprestadas as idéias de Marx Weber, pois o debate sobre os assuntos ambientais na teoria social está embutido nos processos de racio- 
nalização ocidental analisados por ele há cerca de 80 anos. Embora não tenha examinado esse assunto, ele mostrou a existência de uma relação paradoxal entre racionalidade e irracionalidade, que ajuda no entendimento do conflito entre racionalidade instrumental e racionalidade de valor expressa nas imagens divergentes da relação social versus natural (Teixeira \& Bessa, 1997).

Continua quando se indaga se a noção de meio ambiente abrange apenas aquilo que Kant denominou de "mundo das coisas", mundo físico, ou se, no seu interior, cabe o mundo das representações, o mundo das formas. Ou ainda, se é uma questão na qual prevalecem os "nexos utilitários", emergentes a partir da revolução tecnológica, ou, se admitem nexos de significações. Sahlins (1979) considera que "toda ação humana é mediada por um projeto cultural que ordena a experiência prática para além da simples logística utilitária” (apud Silva, 1999:2).

Nesse sentido, propõe-se que a desconstrução aqui sugerida ${ }^{6}$ passe pela própria desconstrução da racionalidade instrumental embutida no arcabouço teórico-conceitual de cada uma das disciplinas que tratam a relação homem-natureza como uma apropriação utilitária; passe também pela desconstrução do planejamento como o maior símbolo desse tipo de racionalidade e, mais especificamente, do planejamento urbano. Acredita-se que somente assim será possível perceber um espaço urbano que, dotado de uma racionalidade própria, desobediente e resistente às prescrições do planejamento, se supera e reinventa formas de (con)vivência, razão pela qual ora é emblemático da irracionalidade máxima de apropriação da natureza pela sociedade, ora de uma outra racionalidade. Portanto, o espaço urbano, para alguns, torna-se o símbolo da irracionalidade e, para outros, ao contrário, de uma racionalidade específica. O que diferencia essa (ir)racionalidade?

Costa (1999) ressalta que, no campo dos estudos ambientais, a dimensão espacial urbana é subestimada e até mesmo negada como não-ambiental. Há uma hostilidade do movimento ambientalista para com a existência das cidades. Para entendê-la, é preciso retornar à origem das preocupações urbana e ambiental. A urbana surgiu com a generalização do capitalismo ocidental urbano-industrial e a consolidação de um projeto de modernidade. A ambiental surgiu das reações às características negativas da organização territorial associada a esse projeto. Embora essa argumentação seja utilizada para mostrar a oposição entre meio ambiente e espaço urbano, na verdade, ela aponta que ambas as posturas estão prisioneiras de uma mesma racionalidade instrumental, o que confirma a necessidade, antes levantada, de se perceber uma outra racionalidade.

Racionalidade que envolve a urgência de quebrar o preconceito dos ecologistas sobre a insustentabilidade dos centros urbanos e a sua crença de que só existem soluções sustentáveis para pequena escala (Costa Filho \& Sattler, 1999). Racionalidade que leva à necessidade de os economistas compreenderem que as externalidades não são apenas econômicas mas também ambientais, ou seja, além do intercâmbio economicamente desigual, é preciso computar o intercâmbio ecologicamente desigual (Alier \& Schlupmann, 1991). Racionalidade que conduz os geógrafos a buscarem a natureza escondida no urbano ou cada vez mais oculta no processo de produção e reprodução do espaço urbano (Rodrigues, 1998). Racionalidade que faz os urbanistas reconhecerem que o meio ambiente natural, quando substituído por espaços urbanos, dá lugar a uma ação antrópica, que cria novas relações e subverte a ordem biológica reguladora da sociedade/natureza, lançando as bases para uma nova ecologia humana (Alva, 1997). Por fim, a racionalidade destacada por Santos (1994), em que a cidade está fadada a ser tanto o teatro dos conflitos crescentes, como o lugar geográfico e político da possibilidade de soluções.
6 Não se pretende, no âmbito deste artigo, realizar a referida desconstrução, mas tão somente apontar a sua necessidade e identificar alguns autores cujas idéias permitem agregar argumentos nessa direção. 
Além disso, o entendimento de uma outra racionalidade no(do) espaço urbano inclui admitir que o tema ambiental evidencia a crise da ciência moderna, porque envolve muitas disciplinas e, portanto, tem um caráter transdisciplinar. Essa complexidade fica mais clara ainda quando se trata do meio ambiente urbano, onde a multiplicidade de áreas do conhecimento empenhadas na apreensão do universo urbano favorece uma visão mais holística da interação do espaço social construído e do seu suporte natural (Mota Silva \& Shimbo, 1999).

Com base nesses recortes do pensamento, argumenta-se, aqui, que a expressão meio ambiente urbano, longe de conter uma contradição, traz a possibilidade de um novo olhar que não é nem ambiental nem urbano isoladamente, mas carrega contradições inerentes ao espaço urbano que definem sua (in)sustentabilidade de acordo com a racionalidade adotada. Esse olhar leva a considerar o meio ambiente urbano como uma área de investigação que trabalha com várias disciplinas, mas precisa necessariamente desconstruir os mitos criados no seio de cada uma delas, para elaborar discursos verdadeiramente inovadores que abandonem a racionalidade instrumental e, conseqüentemente, a insustentabilidade presente na maioria das vertentes teórico-conceituais apontadas.

Para tanto, é fundamental verificar em que bases vem ocorrendo o processo de elaboração de discursos específicos para a área de meio ambiente urbano. Trata-se de um processo tortuoso e repleto de questionamentos que começam pelo modismo, passam pela transformação da questão social urbana em questão ecológica e vão até a perda de identidade da questão urbana.

A visão de Hogan (1995), sobre os problemas urbanos de outrora serem vistos como os problemas ambientais de agora, é emblemática do modismo: "antes da questão ambiental aparecer com a força e a centralidade que tem hoje, esses problemas já estavam nas agendas dos planejadores urbanos e autoridades municipais. A transformação destes problemas de gestão urbana em sinais de saturação ecossistêmica é um marco do ambientalismo contemporâneo. Porém sua identificação como problema e a intervenção do poder público se deram há muito tempo" (apud Ribeiro et al., 1999:10).

Esse tipo de visão coloca em dúvida se o meio ambiente urbano é uma nova área de investigação, uma vez que sugere estar havendo apenas a adoção de um novo "rótulo" para tratar os mesmos problemas. De fato, muitos trabalhos, se considerados em sua temática central - a exemplo dos de Pecchio (1993) e Câmara (1997), que tratam, respectivamente, da ocupação em áreas degradadas e em encostas deslizantes - poderiam ser enquadrados como exemplos dessa afirmação. Entretanto, defende-se aqui que existe uma sensível diferença de abordagem entre analisar um problema urbano de per si e inseri-lo em uma problemática ambiental urbana. Além disso, mesmo admitindo que problemas urbanos como os acima referidos não são novos, é preciso observar que eles sempre impactaram o meio ambiente urbano, embora isso não fosse uma preocupação consciente dos antigos gestores. Há, portanto, uma diferença não só de abordagem mas de contexto. Acrescente-se o fato de alguns autores considerarem que os problemas urbanos, vistos sob a óptica do meio ambiente, podem gerar uma nova agenda de questôes: qualidade de vida, iniqüidades sociais, cidades globais, tensão entre o local e o global (Ultramarini \& Pereira, 1999).

Um segundo tipo de questionamento é trazido por Topalov (1986): a emergência de um novo paradigma, em que o meio ambiente passa a ser o tema central em torno do qual todos os discursos e projetos sociais devem ser reformulados para serem legítimos. Segundo ele, a questão social urbana transformou-se em questão ecológica ou ambiental, ocorrendo uma substituição de paradigmas - o ecocêntrico tomando lugar do sociocêntrico. 
Embora nesse enfoque não haja um questionamento do meio ambiente urbano como área de investigação, pois aparentemente se reconhece a (con)fusão entre questôes urbanas e ambientais, essa é vista segundo uma abordagem que admite como possível a substituição de ambiental por social. Portanto, vê-se exclusão quando deveria haver integração. Por essa razão, Ultramarini \& Pereira (1999) mostram que a cidade pode ser entendida como um ambiente construído ou como um conjunto de espaços construídos que assentam sobre um suporte natural preexistente, progressivamente transformado segundo determinadas lógicas que apresentam uma distribuição dinâmica de usos e funções. Nessa concepção, segundo eles, discutir o ambiente urbano supõe considerá-lo como espaço e suporte natural transformados pelas práticas dos agentes, as quais definem aqueles usos e funções.

Por fim, Costa (1999) traz à tona o questionamento relacionado à perda de importância da questão urbana, como tema de interesse da "critical social theory" contemporânea, pois questôes como raça, gênero e diversidade cultural assumiram a dianteira. Supóese que nos anos 70 havia uma densa área de estudos sobre o urbano ${ }^{7}$ e que nos anos 80 continuou como palco e gerador dos movimentos sociais, mas hoje essa nitidez não é mais possível, embora o mundo seja cada vez mais urbano, pois, ao generalizar-se, deixou de ser um objeto de investigação em si mesmo. ${ }^{8}$ Se isso fosse verdade, como mostra a própria autora, a dimensão ambiental da análise urbana ficaria restrita a redutos mais técnicos (legais ou sanitários, como lixo, água e poluição), ou às práticas políticas e análises de movimentos sociais em torno de conflitos ambientais nas áreas urbanas. Além disso, falar da problemática socioambiental urbana soaria apenas como uma "roupagem da moda para nossas velhas questôes sociais (e urbanas). No entanto, definir e tratar conjuntamente os dilemas sociais e ambientais constitui uma necessidade" (idem:5).

A mesma autora, ao apontar outras análises que se direcionam para uma redefinição do objeto dos estudos urbanos, encarrega-se de destruir o próprio questionamento. Lembrando Smith (1984), ressalta a importância atual dos processos sociais urbanos (culturais e ambientais) que traduzem diferentes formas de sociabilidade e novos usos para os espaços. Cita visóes mais progressistas do planejamento, como a de Soja (1997), que propõe uma teoria pós-moderna do planejamento, uma reestruturação ontológica que encoraje a desordem da diferença e novas (práticas) políticas culturais que vão além das definiçóes binárias em termos de gênero, raça ou classe. Para ela, a expressão meio ambiente urbano sintetiza as dimensões físicas (naturais e construídas) do espaço urbano, dimensões de ambiência e possibilidades de convivência e de conflito, associadas às práticas da vida urbana e a melhores condições de vida, seja no sentido da cidadania, seja da qualidade de vida urbana.

Do que foi dito anteriormente, é possível observar que não se pode olhar o meio ambiente urbano com os olhos de ontem, quando não se tinha consciência da sua existência, tampouco separar o urbano do ambiental. Nesse sentido, nem o espaço urbano nem o meio ambiente isoladamente são substratos do meio ambiente urbano, pois o meio ambiente urbano é uma outra "coisa" que precisa ser vista com um novo olhar.

Os questionamentos apresentados mostram que há resistências em reconhecer o meio ambiente urbano como área de investigação, embora indiquem abordagens que podem conduzir a esse novo olhar. Tais abordagens vêm-se dirigindo para uma desconstrução de mitos sobre a insustentabilidade do espaço urbano e, ao fazê-lo, podem gerar uma definição de meio ambiente urbano. Antes, porém, é preciso conhecer com base em que conceitos e em torno de quais questōes e propostas essa definição se baseia.
7 Cujas teorias mais embemáticas foram as de Castells, Topalov, Lipietz, Harvey e Lojkine.

8 Em apoio a essa argumentação, a autora cita Castells (1996), que considera a busca da identidade como 0 princípio organizador da sociedade atual e, em decorrência disso, os estudos culturais mais precisos do que os urbanos para agrupar identidades. 


\section{AGENDA DE QUESTÕES E PROPOSTAS SOBRE A (IN)SUSTENTABILIDADE DO ESPAÇO URBANO}

Para identificar se as questôes e propostas que compóem a agenda da área de investigação do meio ambiente urbano dão respaldo ao novo olhar acima sugerido, é importante mostrar o entendimento que alguns planejadores/pesquisadores têm sobre três pares de conceitos e noções: ambiente/meio ambiente, desenvolvimento sustentável/sustentabilidade e território/urbanização. Tal entendimento é fundamental para se chegar à idéia de sustentabilidade urbana. Ao longo das últimas décadas, esses conceitos/noçôes ganharam várias acepções e sua presença é uma constante em discursos governamentais, não-governamentais e acadêmicos.

\section{CONCEITOS E NoçÕES BÁSICAS}

Em princípio, parece que ambiente e meio ambiente são equivalentes, uma vez que têm sido usados indistintamente. Entretanto, Vargas (1999) seleciona autores que se referem especificamente a ambiente. Para a Comunidade Européia, é o "conjunto dos elementos naturais que, na complexidade de suas relaçôes, constituem o marco, o meio e as condiçōes de vida do homem”. Para Regales (1997), “o ambiente é um sistema global formado por dois subsistemas: o meio geográfico e o habitat. No meio geográfico inclui-se o meio físico, composto dos elementos naturais existentes na Terra e que fornecem recursos para o exercício das atividades humanas. O meio físico oferece dificuldades e riscos, recebe a marca da criatividade e das inovações culturais, convertendo-se em suporte humanizado. Desse suporte individualiza-se o habitat, que seria o conjunto de assentamentos rurais e urbanos, o tecido construído, onde o homem tem exercido historicamente as funções de relação e interação com o meio geográfico e a natureza, ou meio físico". Por fim, o histórico da palavra ambiente que, segundo Cuter (1985), "teve significado inicial como uma representação simbólica de ambiente construído, onde três dimensões se apresentam: a social (renda, educação, saúde, segurança), a ambiental (clima, aspectos físicos, nível de poluição) e a perceptiva (bem-estar e condições de vida)" (apud Vargas:7-8).

Por outro lado, referindo-se à noção de meio ambiente, Silva (1999) considera que ela vem sendo entendida segundo um determinado recorte histórico-social, razão pela qual não pode ser aceita como uma concepção dada, senão como uma construção. De fato, desde 1993 Vainer perguntava: Qual é o meio ambiente que queremos planejar? De que meio ambiente estamos falando? Para ele, "o conceito de meio ambiente ancora-se num subjetivismo, cuja superação exige entender que o meio ambiente não é uma realidade empírica, mas sim uma construção social". Nessa linha de reflexão, diz: "a questão ambiental deixa de ser vista como produto de uma relação entre o Homem ... e a Natureza ... para situar-se no campo das relaçóes que diferentes grupos entretecem no espaço social, bem como das diferentes estratégias que elaboram com vista ao embate pela apropriação, controle e uso de território e recursos territorializados" (Vainer, 1993:556-7).

Os entendimentos acima, longe de esgotarem o significado dessas noções/conceitos, trazem, ao contrário, cada vez mais indagações que vão surgindo de novos enfoques. Assim, por exemplo: "Considera-se o meio ambiente, o ambiente, a natureza, como um bem comum. Embora apropriado em parcelas, sob a forma de mercadorias, bem comum é um bem de uso coletivo mesmo que apropriado privadamente?" (Rodrigues, 1998:57). 
O reconhecimento de que a cada novo enfoque se acrescentam mais reflexões pode ser lido como uma falta de identidade sobre o entendimento de ambiente e meio ambiente. Entretanto, nesses aparentes desencontros defende-se a possibilidade de uma leitura de encontros, porque o foco sócio-histórico aparece, explícito ou implícito, como um elo capaz de amarrar essas idéias. A ausência de predeterminação do que seja ambiente e meio ambiente é, portanto, a marca não de uma incapacidade de chegar a uma definição única e consagrada, mas de uma certeza de que ela não deve ser encontrada, posto que não existe. Ou, como diriam Lacorte \& Barbosa (1995), contrapõe a impossibilidade de uma teoria geral (abstrata) do meio ambiente à possibilidade de demarcar seu campo específico a partir de uma construção social, historicamente datada.

Quanto ao desenvolvimento sustentável/sustentabilidade ambiental, vale destacar não somente algumas acepções em meio a muitas, mas apenas a polêmica instalada entre aqueles que acreditam na (im)possibilidade de uma relação mais equilibrada entre economia, sociedade e meio ambiente, ante o modelo capitalista prevalecente. Carvalho (1991) identifica "duas matrizes discursivas que interpretam o acontecimento ecológico: a das instituições governamentais e intergovernamentais, que propõem estratégias ecológicas compatíveis com o desenvolvimento industrial capitalista, e a dos movimentos ecológicos, que propõem modos não-predatórios de produção e uma outra ética de relações entre os homens" (apud Rodrigues, 1998:87-8).

No relatório "Nosso Futuro Comum" (1997), entendeu-se que a sustentabilidade deve ser abordada como um horizonte norteador de condutas, isto é, deve ser encarada como um processo permanente e não um fim tangível a ser alcançado e preservado a todo custo. Seguindo esse preceito, o documento "Cidades Sustentáveis da Agenda 21 Brasileira” advoga que a noção de sustentabilidade, enunciada como uma qualidade, vai firmar-se como o novo paradigma do desenvolvimento humano. Tal capacidade de a tudo referir-se, imprimindo a todos os processos uma qualidade que os torna diferentes do que eram antes, faz que a sustentabilidade possa ser afirmada como um paradigma. Para tanto, parte de duas noções-chave: sustentabilidade ampliada e sustentabilidade progressiva. ${ }^{9}$ Tais noções se apóiam em quatro dimensões básicas identificadas no conceito de sustentabilidade: a ética, que considera a vida da própria espécie humana e dos demais seres; a temporal, que estabelece a necessidade do planejamento a longo prazo; a social, que busca o pluralismo político e menos desigualdade; e a prática, que propõe a mudança de hábitos de consumo e de comportamento (MMA/PNUD, 1999).

Nessa mesma linha, Costa considera que "houve um avanço significativo ao se afirmar que não há desenvolvimento que não seja sustentável ... Nesse sentido, a noção de sustentabilidade ambiental corresponde a uma dimensão a ser incorporada à própria noção de desenvolvimento e não um conceito diferente do anterior. O conceito de desenvolvimento sustentável vem-se transformando num enorme guarda-chuva capaz de abrigar uma variada gama de propostas inovadoras que caminham na direção de maior justiça social, de melhoria da qualidade de vida, de ambientes mais dignos e saudáveis, de compromisso com o futuro" (Costa, 1999:7). A despeito disso, ela cita Harvey, para quem todo esse debate é sobre a preservação de uma ordem específica e não acerca da natureza em si.

De fato, outros autores admitem que "a chamada ao desenvolvimento sustentável representa apenas o debate sobre o modelo de desenvolvimento que se pretende e que se quer de fato alcançar". Viola (1996) enumera três posições sobre os locus privilegiados de um novo desenvolvimento social e ambientalmente sustentável: a estatista, a comunitária
9 A sustentabilidade ampliada realiza o encontro político entre a agenda ambiental e a agenda social ao enunciar a indissociabilidade entre fatores sociais e ambientais e a necessidade de enfrentar a degradação do meio ambiente junto com o problema da pobreza. A sustentabilidade progressiva é vista como um processo a ser construído paulatinamente e capaz de romper o círculo vicioso da produção excludente e implantar um círculo virtuoso. 
e a de mercado; as duas primeiras priorizariam a eqüidade, e a última, a eficiência (apud Teixeira \& Bessa, 1997:1883).

Ao contrário, adotando uma postura crítica, há quem admita a existência de uma oposição entre os conceitos de desenvolvimento e sustentabilidade, pois, enquanto o último é fruto de um movimento histórico recente, altamente questionador da sociedade industrial, o primeiro é o conceito-síntese de uma sociedade cujo modelo mostra seu esgotamento ( MMA/PNUD, 1999).

Ainda na linha crítica, Layrargues (1997) argumenta que "o desenvolvimento sustentável adota uma concepção que generaliza os fatos, omitindo o contexto histórico e criando um homem abstrato, desprovido de identidades sociais, econômicas e culturais. Essa conduta retiraria o componente ideológico da questão ambiental" (apud Mota Silva \& Shimbo, 1999:9).

Corroborando essa postura, há autores que apontam para a fragmentação do conceito de desenvolvimento sustentável. Assim: "Em muitos trabalhos se fala de desenvolvimento sustentável agrícola, pecuário, florestal ou urbano, como se cada um destes setores da economia e da sociedade pudesse manejar-se individualmente. Isso significa que ... se pode aplicar uma política de desenvolvimento sustentável agrária e não às cidades? ... O desenvolvimento sustentável deve ser, necessariamente, um conceito que abarca todas as facetas do desenvolvimento, gerando na prática sistemas de manejo específicos em cada setor, porém não para que esse setor seja sustentável e sim para que contribua a que o todo seja" (Reboratti, 1998:8).

Por fim, Rodrigues (1998) considera que o conceito de desenvolvimento sustentável parece jogar uma cortina de fumaça sobre as contradiçōes, pois não reflete alterações no modelo dominante. Para ela, falta visão de classes e visão espacial na proposta de uma sociedade sustentável, cuja aplicação prática só pode ser exeqüível se concretizada no espaço.

Há, portanto, autores que acreditam no desenvolvimento sustentável/sustentabilidade como um paradigma inovador, outros que o consideram apenas um ponto-chave no debate atual e, por fim, os que possuem uma visão mais crítica e alertam para aspectos não contemplados ou para uma utilização distorcida do mesmo. Aqui, não cabe discutir esses posicionamentos. Cabe constatar a dimensão política que perpassa todos eles e questionar a que meio ambiente, em termos espaciais, estão se referindo. Esse questionamento introduz outro par de conceitos: território/urbanização, e traz à tona a relação do es-

10 Para Acselrad (1997), essa relação se tem dado por duas vias: mudanças incrementais em problemáticas convencionais ou crítica aos limites dessas. Enquanto na primeira a queda da qualidade ambiental se associa aos desequilíbrios regionais como um outro tipo de externalidade negativa do crescimento econômico, a segunda incorpora a dimensão ambiental ao estudo dos processos sociais do espaço e, assim, atribui múltiplas significações sociais aos territórios.

\section{paço urbano com a questão ambiental. ${ }^{10}$}

Segundo Acselrad (1997), para que a noção de sustentabilidade faça parte dos projetos de atores sociais territorializados, é preciso caracterizar o contexto sociopolítico em que emerge o seu discurso. Discorrendo sobre os caminhos desse debate, ele chega a uma indagação: "haveria brechas para um desenvolvimento apoiado na diversidade das formas sociais e dos recursos territorializados - um novo princípio ordenador do espaço?" Para ele, "espaço, território, meio ambiente são objetos das lutas sociais aos quais os atores sociais atribuem distintos sentidos". Argumenta que se trata de "uma disputa entre diferentes projetos sociais territorializados ... de evidenciar as perspectivas dos sujeitos sociais que procuram dar às distintas configurações sócio-espaciais sentidos diversos daqueles impostos pelo regime de acumulação dominante - movimentos contra-hegemônicos - concepção de sustentabilidade abriga pactos políticos" (Acselrad, 1997:1919-20).

Para Friedmann, "o território coincide com o espaço de vida ... a territorialidade existe a todas as escalas, da maior à menor, e somos simultaneamente cidadãos de várias comunidades territoriais ... a territorialidade é uma das mais importantes fontes das 
ligaçôes humanas: cria uma comunidade, ligando o presente ao passado como fundo de memórias comuns (História) e ao futuro como um destino comum; a territorialidade alimenta uma ética de cuidados e preocupações pelos concidadãos e pelo ambiente que partilhamos com eles" (Friedmann, 1996:143-4).

A simultaneidade dos cidadãos em várias comunidades territoriais que Friedmann ressalta é a base da reflexão de Monte-Mór \& Costa (1997), que se propõem a repensar o conceito de urbanização, dado que ele contraria inúmeras situações contemporâneas, a exemplo dos trabalhadores rurais moradores de periferias urbanas. ${ }^{11}$ Para eles, uma nova definição de urbanização deve incluir diferentes níveis de urbanidade e ruralidade, buscando privilegiar seus impactos antrópicos sobre o meio ambiente.

Os três pares de conceitos acima apresentados são como raízes para se entender o que é sustentabilidade urbana. Isso equivaleria a dizer que, em princípio, todas as afirmações, as ambigüidades e as críticas, antes ressaltadas, estariam sendo transpostas para cá. Levaria, portanto, a indagar se a sustentabilidade urbana é tão simplesmente um conceito/noção derivado dos anteriores, ou possui uma identidade própria. Ou a indagar, ainda, se o adjetivo urbana imprime uma leitura à sustentabilidade específica e isolada de outras "sustentabilidades".

Parece que a sustentabilidade urbana cobre, em grande parte, as lacunas e os questionamentos apontados, principalmente porque é intrinsecamente espacial e encerra as contradiçõos sociais que se exacerbam no espaço urbano. Entretanto, essas características não significam que ela pode ser vista isoladamente nem prescindir de um planejamento. Ao contrário, cada vez mais se trabalha a idéia de planejar a sustentabilidade urbana além dos limites da cidade.

É a característica paradigmática da sustentabilidade que dá suporte à possibilidade de uma sustentabilidade urbana, admitindo que o desenvolvimento urbano possa ocorrer em bases sustentáveis (MMA/PNUD, 1999). Essa possibilidade carrega ideais de intervenção urbana via planejamento. Meyer (1997) acredita que, a despeito da crise do planejamento, ele ainda é a principal ferramenta para se atingirem os ideais de sustentabilidade urbana. Afirma que essa crise não pode confundir-se com a idéia de fracasso e fim da cultura do planejamento urbano, e sim induzir a um momento de reflexão e reformulação que passa a integrar e redefinir o lugar que devem ocupar as questôes ambientais dentro do quadro da gestão urbana. Essa premissa deixa implícita a necessidade de se refletir sobre o tipo de planejamento a ser adotado. Nesse sentido, o mesmo autor ressalta que uma das mais evidentes questôes para o desenvolvimento sustentável é que ele requer a presença e a negociação das várias formas de capital: financeiro, natural, tecnológico, cultural, e físico (apud Ribeiro et al., 1999).

Assim, a sustentabilidade urbana decorre da não-submissão das políticas aos interesses do capital privado. Decorre, ainda, da contextualização dessas políticas a um espaço geográfico que transcende os limites da cidade. Esse é o pensamento daqueles que vêm desmitificando o sucesso do modelo de Curitiba, como capital humana, ecológica e tecnológica, mostrando que seu planejamento não levou em conta os vários agentes envolvidos nem o entorno e a região metropolitana em geral (Moura et al., 1999).

Outros autores também se referem, explicitamente, à transcendência dos limites da cidade. Vargas (1995), analisando o Plano Diretor de Cubatão, destaca que suas propostas se dirigiram a dois níveis de intervenção: o regional e o local. Referindo-se ao Zoneamento Econômico-Ecológico (ZEE), Steinberger (1997) aponta para a importância de se perceber o território urbano-regional e não o urbano e regional separados, e Kohls-
11 Para Monte-Mór \& Costa (1997), o conceito de urbanização refere-se a um processo de assentamento humano, espacialmente concentrado em unidades de complexidade variável: cidades, vilas, megalópoles, povoados etc. Tal processo implica formas de inserção econômica não diretamente ligadas ao trabalho da terra ou à exploração de recursos naturais, ambas associadas ao ciclo da natureza. Por oposição, atividades industriais e terciárias são tidas como essencialmente urbanas. 0 mesmo tipo de argumento, na sua vertente antropológico-sociológica, associa urbanização a um determinado modo de vida, no qual se confundem variáveis como: valores, comportamentos, atitudes individuais e coletivas, acesso à informação, bens e serviços, estilos de vida, (busca de) formas de morar, trabaIhar e locomover-se, um sem-número de atividades associadas ao não-trabalho, capacidade ou risco de exposição a mudanças que se processam velozmente... Esse modo de vida não é necessariamente único no tempo e no espaço, mas é certamente diferenciado daquele associado à vida rural. 
dorf \& Romero (1997) ressaltam que a abordagem ambiental do ZEE em regiōes urbanizadas deveria contemplar a integração de vários tipos de unidades ambientais: urbanas, periurbanas e rurais. Monte-Mór \& Costa (1997) identificam a coexistência de várias formas de urbanização na Região do Vale do Piracicaba mineiro, a exemplo de cidades de porte médio, povoados rurais, distritos em fase de emancipação e transferência para outros municípios, núcleos estagnados, áreas urbanas conurbadas e uma área metropolitana em consolidação.

Além disso, há autores que ressaltam essa transcendência no âmbito teórico. Para Breheny (1992), "o debate recente sobre a cidade ecologicamente sustentável tem o mérito de reunir questões urbanas e regionais até então compartimentadas" (apud Costa, 1999:10). Para Tudela (1997), a cidade consiste em um "complexo intercâmbio de matéria, energia e informação que a entidade urbana estabelece com territórios por vezes bastante distantes" (apud Ultramarini \& Pereira, 1999:5).

Essa seleção de noções/conceitos básicos permite identificar um rumo bastante fértil de convergência sobre sustentabilidade urbana, baseada em uma outra racionalidade não-instrumental: os focos sócio-histórico e político-espacial. Tais focos começam a aparecer na discussão de ambiente/meio ambiente. Ganham mais nitidez nos posicionamentos críticos sobre desenvolvimento sustentável/sustentabilidade, e nas abordagens de território/urbanização, quando incorporam a dimensão política e as preocupações espaciais.

\section{Questóes Centrais e Propostas Delas Decorrentes}

Na leitura do conjunto dos trabalhos apresentados nos Encontros da Anpur dos anos 90 , constata-se um número significativo de textos sobre impactos urbanos e regionais de grandes projetos dos setores elétrico, industrial, de saneamento e habitação, nos quais são discutidas propostas para dirimir os conflitos entre os atores. Outro grupo de autores, também significativo, aborda a qualidade de vida, em suas várias acepçōes. Percebe-se, ainda, que boa parte dos autores centra suas análises em estudos de caso voltados para a aplicação de instrumentos de gestão, oferecendo contribuições sobre como se pode atingir a sustentabilidade urbana. São poucos aqueles que se ativeram a uma abordagem eminentemente teórica, embora, em quase todos os trabalhos, exista um embasa-

12 Conforme foi dito na Introdução, o objetivo deste artigo não é realizar um balanço do conhecimento produzido nos Encontros da Anpur dos anos 90 , razão pela qual não serão elaboradas tabelas sobre a tipologia dos 39 trabalhos analisados. mento teórico-conceitual. ${ }^{12}$

Dada a amplitude das questóes envolvidas na área de meio ambiente urbano, alguns autores, como Metzger (1994), sugerem agrupar a produção científica em uma tipologia: - a natureza dentro da cidade (natureza biológica; pedaços de natureza - áreas verdes; e elementos físico-naturais - hidrologia, pedologia e climatologia urbana);

- os riscos de morar na cidade (biológicos - proliferação de bactérias; físico-químicos poluição do ar e da água; tecnológicos - poluição industrial; morfo-climáticos e naturais; de saúde; e de violência e segurança); e

- a gestão da cidade (políticas de abastecimento de água, de drenagem e de dejetos urbanos; o planejamento do uso do solo, os transportes e o crescimento urbano; e os aspectos políticos, econômicos, sociais e físicos da formulação de políticas públicas de gestão da cidade, incluindo os atores e a democratização da gestão).

A despeito de a contribuição de Metzger ser fundamental para mostrar a abrangência da área de meio ambiente urbano, observa-se que a maioria dos trabalhos produzidos no âmbito da Anpur mesclou esses grupos. Embora o ponto de partida seja, de fato, as questóes da natureza e risco, via de regra também se chega à gestão da cidade. Há, portanto, 
um modelo misto de apresentação de trabalhos, demonstrando que os planejadores/pesquisadores brasileiros têm sempre em mente a inquietude da busca de soluçôes. Assim, entre as questôes examinadas, três despontam como centrais, porque servem de base para reconstruir e desconstruir mitos sobre o espaço urbano: a qualidade ambiental da vida urbana, os instrumentos de gestão ambiental e o conflito de interesses entre os atores. ${ }^{13}$

A qualidade ambiental da vida urbana é, geralmente, rotulada como qualidade de vi$\mathrm{da}$, qualidade de serviços ou qualidade ambiental. A preocupação dos pesquisadores com essa questão aparece não só na discussão do significado de qualidade mas, principalmente, na sua mensuração, tomando por base a farta literatura já existente sobre o assunto. Portanto, a maioria das propostas se dirigem à identificação de parâmetros e à definição de indicadores e modelos.

A idéia de qualidade em contraposição à de quantidade, segundo Bernal (1994), nasceu no mundo da empresa privada, nos anos 50 . Concebida, inicialmente, como aptidão dos produtos em relação aos usos, passou a significar satisfação de necessidades e hoje é entendida como atendimento a certas especificaçôes. Por outro lado, o mundo dos serviços públicos, de acordo com Chevalier (1987), apresenta uma dimensão ideológica que constitui o denominado "mito legitimante", base do Estado do Bem-Estar Social, em que o acesso e o padrão de qualidade dos serviços deve ser igual para todos. Nesse mundo, ao contrário do anterior, não há clientes que realizam uma demanda ativa, mas usuários que realizam uma demanda passiva (apud Brito, 1997).

Nos dias de hoje, com a agonia do Estado do Bem-Estar e a força da privatização, em tese só haveria clientes. Nesse sentido, a tendência é de que, cada vez mais, a qualidade ambiental seja avaliada por critérios econômicos que medem o desempenho dos serviços. Kohlsdorf \& Romero (1997), cientes dessa imposição, propõem que critérios simbólicos, expressivos e culturais passem a ser contemplados por meio de análises bioclimáticas e de percepção ambiental. Na mesma direção, Ultramarini \& Pereira (1999) consideram que a definição de um padrão de qualidade ambiental sempre esbarra na dificuldade de se estabelecer uma neutralidade, pois os indicadores estão impregnados de valores socioculturais, políticos e econômicos da sociedade ou da instituição que os determinou. Partindo dessa constatação, propõem que a discussão sobre qualidade de vida não deve ser feita à revelia das percepções e experiências da população envolvida.

A despeito disso e reconhecendo essas dificuldades, alguns pesquisadores, a exemplo de Filho et al. (1999) propõem uma metodologia para a construção de indicadores por meio de modelos. Eles estão conscientes de que a mensuração da qualidade de vida é uma atitude pretenciosa e eivada de subjetivismo, porque o conceito de felicidade e bem-estar físico e psíquico não se submete a quantificação. Entretanto, consideram que existem alguns parâmetros pacificamente aceitos, como acesso à educação, saneamento básico, equipamentos de lazer, habitação e nível de renda. ${ }^{14}$ Vargas (1999), em busca de uma definição de qualidade ambiental urbana, também lança mão de vários autores ${ }^{15}$ para chegar a uma listagem de quatro aspectos principais: espacial (bem-estar, desenho urbano, referenciais, uso e ocupação do solo); biológico (saúde física, saúde mental, segurança); social (organização, realização pessoal, contatos, atividades, realização profissional, acesso e opções), e econômico (oportunidades, produtividade, diversidade).

Esses esforços, pela extensa lista de autores consultados e variáveis envolvidas, parecem demonstrar que a questão da qualidade de vida, tornada mais complexa nos anos recentes com a introdução da dimensão ambiental, está longe de ser solucionada via modelos e definições, por mais amplos que sejam. Por que não se render à evidência de que as
13 Além dessas três questões, não se pode deixar de fazer referência a outras pelo caráter de inovação e de destruição de certos mitos: planejamento por análise de desempenho (Silva et al., 1999), cidades compactas (Costa, 1999), cidade ecologicamente sustentável (Amaro, 1999), cidades conservadoras de energia (Meier, 1981, apud Friedmann, 1996), "good practices" (UItramarini \& Pereira, 1999), ecourbanismo (Marques da Silva,1999) e política de "city marketing" (Vargas, 1995; Moura,1999).

14 Realizam uma revisão bibliográfica de autores que vêm tratando o assunto, entre os quais Jansen (1959), Schneider \& Simons (1971), Smith (1977), Ben-Chieh Liu (1978), Clark \& Wilson (1994), Lemos (1995) e Krafta (1997).

15 Tais como Lynch (1960), Maslow (1966), William \& Deak (1970), Dalkey (1972), Comune \& Campino (1980), Chiavenato (1988) e Belgiojoso (1992). 
16 Embora a palavra gestão tenha vários significados, um dos mais freqüentemente utilizados é 0 adotado pelo Plano Diretor da Cidade de Recife: "Processo que envolve o planejamento ... a mediação ... a regulação ... e a intervencão com base na pluralidade de interesses negociados entre os agentes" (apud Vergara, 1995:311).

17 Plano diretor, zoneamento de uso do solo e parcelamento do solo urbano.

18 Mercados de direitos de utilização ou direitos ambientais negociáveis, taxas e tarifas, auxilios financeiros.

190 Zoneamento Ambiental de Ribeirão Preto, o Relatório de Impacto Ambiental Urbano de Londrina, o Sistema de Avaliação de Desempenho Urbano de Porto Alegre, o Índice de Qualidade de Vida Urbana de Belo Horizonte e os Estudos de Impacto de Vizinhança de São Paulo.

20 Segundo Câmara (1997), a exclusão espacial é entendida como exclusão - das áreas ocupadas ilegalmente por populações pobres dos processos formais de urbanização ou de planejamento. Por outro lado, o risco de expulsão com possibilidade de perda total dos bens duramente adquiridos e o risco à saúde resultante da ausência de saneamento tornaram-se problemas menores diante do risco de vida, ameaçada pelos deslizamentos de terra ou desabamento da própria moradia.

21 Como o da matriz de interação causa/efeito (matriz de Leopold). Sobre as críticas, ver Ron Bisset \& Witliam Kennedy (apud Sá et al.:1995:).

22 Via educação ambiental, entre outras propostas. receitas gerais faliram e que cada território e cada lugar é um caso a ser definido pela população envolvida, com o auxílio dos planejadores? A esse respeito, Rypkema diz que o caráter do ambiente construído está diretamente relacionado não só com a força das comunidades como também com a qualidade do lugar (apud Pereira Costa,1999).

A segunda questão central, levantada nos trabalhos da Anpur, está ligada aos instrumentos de gestão ${ }^{16}$ ambiental. Em geral, é apresentada sob a forma de críticas relativas à distorção no uso dos instrumentos ou à insuficiência dos mesmos. De Angelis (1999) organizou um quadro de instrumentos de gestão ambiental, entre os quais incluiu os urbanísticos, os econômicos, os educacionais e os informativos. Estudou mais detidamente os urbanísticos $^{17}$ e os econômicos. ${ }^{18}$

Em relação aos urbanísticos, a inserção do viés ambiental no planejamento urbano tem ocorrido por meio da aplicação de leis federais, como a 6.766/79, e dos planos diretores municipais que, recentemente, passaram a conter capítulos sobre o meio ambiente. A despeito disso, constata-se que a generalidade no tratamento da questão ambiental é uma característica das legislaçôes municipais, embora haja algumas exceções ${ }^{19}$ (Ribeiro et al., 1999). Em decorrência disso, os instrumentos urbanísticos não têm dado conta de resolver os problemas de desqualificação ambiental que geram exclusão espacial e risco de vida. ${ }^{20}$

No que se refere aos instrumentos econômicos, segundo Acselrad, manuais acadêmicos e organismos multilaterais insistem na superioridade dos instrumentos de mercado para combater a degradação ambiental. Apoiados no paradigma econômico neoclássico da alocação eficiente dos recursos, propõem instrumentos de internalização dos custos ambientais, partindo da noção de externalidade como um fenômeno extra-econômico. Sugerem que a degradação do meio ambiente resulta de brechas de mercado por onde a alocação dos recursos se afasta de uma situação ótima: "Internalizar é portanto ... travestir um problema de poder em um problema de eficiência alocativa". Como diz Lerner (1972), "esta solução consistiria em transformar o conflito - um problema político - em uma transação econômica; e uma transação econômica é um problema político resolvido". Na opinião de Acselrad, "o que se faz necessário é a explicitação política dos conflitos ... como lembra Przeworski (1993), pois no processo de construção democrática o problema não se reduz ao confronto do mercado contra o Estado, mas concerne em identificar mecanismos institucionais específicos capazes de oferecer a determinados agentes econômicos, incluindo o Estado, incentivos e informação que os levem a se conduzir de uma maneira coletivamente racional" (Acselrad, 1995:274-5).

Outro instrumento usado com fins econômicos, embora de caráter preventivo, é o Estudo de Impacto Ambiental, baseado em avaliaçôes que lançam mão de métodos bastante conhecidos, mas severamente criticados. ${ }^{21}$ Alguns autores avaliam que as metodologias dos estudos ambientais de usinas hidrelétricas funcionam como um instrumento de manipulação das questōes sociais. Argumentam que a noção de impacto despreza as condições em que as populações se apropriam do território e dos recursos naturais, bem como as formas pelas quais constroem seu mundo social e as representaçôes acerca dele (Lacorte \& Barbosa, 1995).

Por fim, seguindo as tendências atuais em termos de planejamento participativo e estratégico, os trabalhos da Anpur sobre a terceira questão central - o conflito de interesses entre os atores - estão permeados por propostas de conscientizar ${ }^{22}$ e organizar os diversos segmentos da sociedade visando a uma participação mais coletiva. Nessa linha, Lassonde (1996) afirma que o surgimento da questão ética nos debates contemporâneos 
provém do fato de que estamos num ponto da história em que "os homens podem ser individualmente inocentes e coletivamente responsáveis, todos vítimas e culpados ao mesmo tempo" (apud Vargas, 1999:1).

Em termos mundiais, a emergência do movimento de conscientização ambiental começou na década de 1960, mas o marco foi a Conferência de Estocolmo, em 1972, que gerou o lançamento do Programa Internacional de Educação Ambiental, em 1975. Nele, a educação ambiental foi definida como "uma dimensão dada ao conteúdo e à prática da educação orientada para a resolução dos problemas concretos do ambiente, através de enfoques interdisciplinares e de uma participação ativa e responsável de cada indivíduo e da coletividade" (Silva, 1999:4).

Pecchio (1995) constata que amplas camadas da sociedade urbana não relacionam seus problemas cotidianos ao meio ambiente urbano, pois ainda não perceberam seu papel como agentes de mudança da própria realidade. Nesse sentido, considera que o processo de politização do meio ambiente, no Brasil, passou por dois estágios: o meio ambiente como matéria de intervenção estatal institucionalizada, desde os anos 70 até finais dos 80, e a partir daí a valorização do papel político dos agentes sociais. Poley (1993) acrescenta que o primeiro estágio foi marcado pela presença de movimentos apolíticos de denúncia da degradação ambiental e de comunidades alternativas rurais, e que somente com a Eco-92 ocorreu uma politização explícita do meio ambiente, por meio da denominada "opção ecopolítica". Para ele, "o movimento ecológico se estrutura diante de dois fatos principais: a degradação social e a degradação ambiental". ${ }^{23}$

Essa politização do meio ambiente tem trazido à tona uma série de conflitos de interesses. Alguns casos foram objeto de análise por pesquisadores da Anpur, que denunciam os artifícios, os argumentos e as estratégias utilizados pelos vários atores envolvidos no jogo de poder. O gerenciamento dos recursos hídricos da represa Billings, em São Paulo, revela a força da aliança do governo do Estado com os industriais contra os governos locais e os ambientalistas, ao usar o expediente da negociação em separado com base em uma decisão técnica (Pacheco, 1993). A utilização da estratégia de "atuação responsável", no pólo petroquímico de Camaçari, para enfrentar o desgaste da imagem empresarial devido à poluição que coloca em risco a segurança industrial e a saúde da população, é um exemplo da fraqueza das lutas dos trabalhadores e das comunidades urbanas, dado o seu baixo nível de organização (Borges \& Franco, 1997). Nessa mesma linha, o comprometimento de propostas, como a do "selo verde", no caso da indústria siderúrgica de Minas Gerais, cuja imagem negativa pode acarretar perda de mercado, aparece sob a forma de resistência das empresas em negociar termos de compromisso, contestar multas e exercer pressōes políticas acobertadas pelo governo do estado (Torres et al., 1997). A relação entre empresários e pescadores artesanais organizados em torno do problema de despoluição da baía de Guanabara, analisada segundo a responsabilidade social do empresariado e sob o postulado da ecologia com justiça, mostra a pouca disposição deste último para uma mudança além da mudança conservadora (Teixeira \& Bessa, 1997). A desvalorização das práticas culturais territorializadas de grupos sociais locais organizados, em detrimento de estratégias despolitizadoras dos governos federal e estadual, no caso da implantação da usina hidrelétrica de Tucuruí, mostra a redução utilitária do meio ambiente (Silva, 1999). A semelhança dos problemas de saneamento entre o Rio de Janeiro e Brasília, capitais implantadas em sítios escolhidos por razões de Estado, aponta o conflito entre soluçōes técnicas e políticas (Carvalho \& Romero, 1999). Por fim, no caso da implantação da usina de Serra Mesa, ainda não se estabeleceu um conflito em torno dos possíveis
23 Nesse contexto, afirma que "as questões ambientais enfrentadas pelos ecologistas do primeiro e terceiro mundos são de natureza similar, mas as questões sociais são radicalmente diferenciadas" (Poley, 1993: 535). 
efeitos perversos (redefinição e extinção de espaços), porque há um clima otimista por parte da população que tem grandes expectativas sobre o aproveitamento econômico do lago para lazer e turismo (Guedes \& Natal, 1997).

Embora nem todos esses casos se refiram especificamente ao espaço urbano, na maioria deles atores urbanos estão envolvidos. Além disso, sugere-se aqui que o espaço urbano é, por excelência, o locus para a discussão de conflitos ambientais, uma vez que nele estão congregados e representados interesses territoriais distintos.

As abordagens apresentadas sobre cada uma das questôes centrais vêm contribuindo para reconstruir os mitos estabelecidos sobre a insustentabilidade do espaço urbano do que para desconstruí-los. Assim, quando se diz que a qualidade ambiental da vida urbana é ruim, que os instrumentos de gestão são insuficientes ou precários para tornar o espaço urbano sustentável e se admite que os conflitos de interesses são insuperáveis, está-se contribuindo para alimentar mitos já existentes, reconstruindo-os. Entretanto, quando se propõe inserir a participação e o significado de qualidade ambiental para cada comunidade, explicitar os conflitos dos instrumentos de gestão, ao invés de minimizá-los, e politizar o meio ambiente, caminha-se no sentido de iniciar uma desconstrução de mitos.

\section{Uma Definição de Meio Ambiente Urbano}

\section{a Partir de Discursos Próprios e de um Repensar sobre o Espaço Urbano}

A recente disseminação de questóes e propostas construídas em torno da busca da sustentabilidade urbana vem gerando uma demanda de discursos próprios sobre o meio ambiente urbano como área de investigação.

Reboratti (1998) mostra que os pesquisadores têm chegado ao tema ambiental, analisando-o de muitas formas: "Todos reunidos ao redor de uma temática comum, porém fragmentada e deformada pela adoção de escalas territoriais, temporais e disciplinares diferentes, que vão do local ao global, do individual ao coletivo, do estritamente atual ao que sucedeu no fundo da história”. Paralelamente, ele considera que o aparecimento do tema ambiental nas análises urbanas se insere de um modo diferente, pois não se trata de um ambiente "natural", mas de um ambiente altamente artificializado e degradado. Para ele "a cidade é ... uma grande produtora de degradação ambiental, já que concentra emissão de gases, produção de resíduos de todo tipo, líquidos e sólidos, hiperconsumo de água e escassa capacidade para regenerá-la, destruição da flora e da fauna, geração de altos níveis de contaminação sonora" (Reboratti, 1998:3,5).

Embora essa afirmação possa ser chocante porque visualiza o espaço urbano como insustentável, ela é a justificativa de praticamente todos os discursos que vão em busca da sustentabilidade. As cinco matrizes discursivas, que se remetem à sustentabilidade do território (que incluem o urbano), apontadas por Acselrad (1997), se bem que bastante diferenciadas nas propostas, estão todas impregnadas de um temor efetivo ou potencial da degradação ambiental. Assim, está a matriz da busca da eficiência combatendo o desperdício, a matriz do respeito à escala que advoga limites ao crescimento econômico, a matriz do reconhecimento da desigualdade social e da pobreza a ser reduzida com eqüidade, e também a da crença na auto-suficiência das comunidades tradicionais e a da observância de uma ética baseada na conduta humana com deveres e obrigaçôes. O mesmo pode ser dito quando, dois anos depois, ele identifica três matrizes discursivas teóricas de sustentabilidade urbana que correspondem a representações distintas da cidade: a representação tecnomaterial da cidade sustentável, que inclui modelos de racionalidade 
ecoenergética e de equilíbrio metabólico; a cidade como espaço da qualidade de vida que inclui modelos de pureza, de cidadania e de patrimônio, e a cidade como o espaço de legitimação das políticas urbanas (Acselrad, 1999).

Assim, discursos não faltam, mas a linha divisória entre a (in)sustentabilidade neles inserida é mais tênue do que parece. Analisando esses discursos, observa-se que há várias leituras de (in)sustentabilidade do espaço urbano, ou seja, para cada discurso uma leitura, razão pela qual alguns autores falam de sustentabilidades. Além disso, embora aqui se esteja propondo uma desconstrução de mitos, verifica-se que a maioria dos discursos sobre o meio ambiente urbano se apropria dos marcos teórico-conceituais estabelecidos, reconstruindo-os em cima dos mesmos mitos.

Alguns pesquisadores, preocupados com esse tipo de visão, consideram que ocorreu a propagação de uma mentalidade patológica sobre o meio ambiente urbano, desde que "a maioria das referências sobre a relação meio ambiente/meio urbano estão obnubiladas pelo estigma dos malefícios urbanos e suas conseqüências sobre a degradação do meio ambiente" (Steinberger, 1995:326). Noutras palavras, é fundamental rever os discursos que tomam o espaço urbano como "espaço morto", revisando o próprio modelo territorial urbano para buscar alternativas que garantam maior integração entre o espaço natural e o espaço social (Monte-Mór, 1994).

Nesse sentido, os discursos de sustentabilidade, em geral, estão presos a diagnósticos de insustentabilidade. Entretanto, pode-se encontrar discursos de dois tipos: os que fazem uma mera transposição de mitos apoiados na racionalidade instrumental, ou seja, os reconstruídos em cima de discursos antigos que correspondem praticamente a reedições - e existem as formulações mais recentes que, de fato, desconstroem mitos para elaborar discursos novos. Estes últimos serão a base de uma nova definição de meio ambiente urbano.

Acselrad (1997) considera que a apreensão das condições sociais de apropriação do território pelos discursos ambientais passa por duas questôes: a construção de uma problemática ambiental liberta do determinismo ecológico e do reducionismo biológico e os diferentes tipos de racionalidade que articulam a reprodução social à reprodução da base material do desenvolvimento. Com relação à primeira, alinha cinco frentes de discussão: desmaterializar o meio ambiente, desnaturalizar o meio ambiente, compreender as práticas de poder sobre recursos territorializados, criticar a Sociologia do meio ambiente como subdisciplina da Sociologia das técnicas e liberar a problemática ecológica dos limites do paradigma da escassez. Quanto à segunda, ele identifica uma racionalidade ligada à conservação social e outra à transformação social. Esta última entende que a ação do homem no mundo é mediatizada por um projeto cultural que ordena a experiência prática para além da simples lógica utilitária e comporta projetos de mudança social na direção de valores como eqüidade, democracia, diversidade cultural, auto-suficiência, ética.

$\mathrm{Na}$ mesma linha, outros autores também se referem a propostas alternativas que consideram importante uma visão histórica e interdisciplinar e interagem preocupações da ecologia com análises sociopolíticas, passando pela Geografia, pelo Direito e pela Filosofia. A denominada "crítica socioambiental urbana", que privilegia a análise da questão ambiental urbana como expressão do atual estágio do capitalismo, discute os grandes condicionantes que estão por trás, quais sejam, a racionalidade instrumental e a interpretação mecanicista da natureza (Cidade, 1995). Outras abordagens favorecem a "convergência entre o social, o urbano e o ambiental: análises das práticas e movimentos que se articulam em torno dos conflitos socioambientais; a história ambiental que vem contribuindo para 
Marilia Steinberger, economista, é professora do Departamento de Geografia da Universidade de Brasília. E-mail: rtlia@solar.com.br romper as fronteiras analíticas convencionais do tipo urbano - rural, construído - intocado, social - natural, privilegiando narrativas interdisciplinares e possibilitando uma (re)interpretação da produção e apropriação de nossos espaços" (Costa, 1999:14).

Esses novos discursos vêm gerando alguns enunciados sobre o que se entende por meio ambiente urbano: meio ambiente urbano enquanto espaço e suporte natural apropriados no cotidiano da população (Ultramarini \& Pereira, 1999); meio ambiente urbano como um espaço que possui uma dinâmica ambiental própria e única, resultante da interação entre o ambiente natural e o ambiente construído, cuja harmonia é intrínseca e não extrínseca (Steinberger, 1995). Meio ambiente urbano compreende o conjunto de edificações, sua história e memória, seus espaços segregados, a infra-estrutura e os equipamentos de consumo coletivos (Rodrigues, 1998). O meio ambiente urbano não pode ser um sistema em que os elementos funcionem ou não funcionem, mas um produto, um resultado de qualquer coisa que se assemelhe a relaçóes sociais implicando materialidade, aplicando-se nas coisas reais e virtuais (Metzger, 1994).

Mostrou-se antes que meio ambiente urbano é uma outra "coisa". Coisa que resulta do sistema de objetos e ações que Milton Santos propõe na sua obra $A$ natureza do espaço (1996) e leva a propor que o espaço urbano, ao gerar um meio ambiente urbano artificial, amálgama do natural, do construído e até mesmo do virtual, tenha uma leitura de sustentabilidade que é fruto de uma racionalidade não-instrumental.

Portanto, o meio ambiente urbano como área de investigação não substitui nem se sobrepõe ao planejamento urbano e regional, mas deve ser cada vez mais incorporado a ele, o que, de certa maneira, permite um repensar sobre o espaço urbano.

\section{REFERÊNCIAS BIBLIOGRÁFICAS}

ACSELRAD, H. "Internalização de custos ambientais: da eficácia instrumental à legitimidade política". Anais do $6^{\circ}$ Encontro Nacional da Anpur. Brasília, 1995.

"Sustentabilidade e território nas Ciências Sociais". Anais do 70 Encontro $\mathrm{Na}$ cional da Anpur. Recife, v. 3, 1997.

"Discursos da sustentabilidade urbana". Revista Brasileira de Estudos Urbanos e Regionais, no 1, maio, 1999.

ALVA, E. N. Metrópoles (in)sustentáveis. Rio de Janeiro: Relume Dumará, 1997.

ALIER, J. M.; SCHLUPMANN, K. La ecología y la economía. México: Fondo de Cultura, 1991.

AMARO, J. J. V. "Uma discussão sobre a fundamentação da teoria econômica para o desenvolvimento urbano sustentável”. Anais do $8^{\circ}$ Encontro Nacional da Anpur. Porto Alegre, 1999.

BARBOSA, B. F. "Determinantes locacionais e ganhos econômicos: aspectos importantes num sistema de coleta e disposição de resíduos sólidos". Anais do $7^{\circ}$ Encontro $\mathrm{Na}$ cional da Anpur. Recife, 1997.

BORGES, A.; FRANCO, A. "Mudanças de gestão, mercado de trabalho e periferia metropolitana: o reforço da precarização e os limites da cidadania”. Anais do $7^{\circ}$ Encontro Nacional da Anpur. Recife, 1997.

BORNHEIM, G. A. "Filosofia e política ecológica." In: MACIEL, T. B. (Org.). O ambiente inteiro: uma contribuição critica da Universidade à questão ambiental. Rio de Janeiro: UFRJ, 1992. 
BRASIL/CIMA. O desafio do desenvolvimento sustentável - relatório do Brasil para a Conferência das Naçôes Unidas sobre Meio Ambiente e Desenvolvimento. Brasília, Secretaria de Imprensa da Presidência da República, 1991.

BRITO, A. L. N.P. "Qualidade de serviços de saneamento e qualidade de vida urbana em assentamentos populares: uma discussão da proposta do Programa Favela-Bairro". Anais do $7^{\circ}$ Encontro Nacional da Anpur. Recife, 1997.

CÂMARA, M. P. de A. "Exclusão espacial na cidade contemporânea - do risco de expulsão ao risco de vida". Anais do $7^{\circ}$ Encontro Nacional da Anpur. Recife, 1997.

CARVALHO, E. A. de; ROMERO, M. B. "A insustentabilidade do desenvolvimento urbano das capitais brasileiras". $8^{\circ}$ Encontro Nacional da Anpur. Porto Alegre, mimeo., 1999.

CHRISTOFOLETTI, A. "Impactos no meio ambiente ocasionados pela urbanização no mundo tropical." In: SOUZA et al. (Org.). Natureza e sociedade de hoje: uma leitura geográfica. São Paulo: Hucitec-Anpur, 1994.

CIDADE, L. C. F. "A questão ambiental urbana: perspectivas de análise. Anais do $6^{\circ}$ Encontro Nacional da Anpur. Brasília, 1995.

COSTA, H. S. de M. "Desenvolvimento urbano sustentável: uma contradição de termos?" 8o Encontro Nacional da Anpur. Porto Alegre, mimeo, 1999.

COSTA FILHO, A.; SATTLER, M. A. "Considerações acerca da adaptação do conceito de sustentabilidade ao estudo do desenvolvimento urbano". $8^{\circ}$ Encontro Nacional da Anpur. Porto Alegre, mimeo., 1999.

DE ANGELIS, B. L. D.; DE ANGELIS, N. G. Utilização de instrumentos de gestão para o controle ambiental em áreas urbanas". 80 Encontro Nacional da Anpur. Porto Alegre, mimeo., 1999.

FERREIRA, F. P. M. "O Estado e o movimento ecológico na Amazônia brasileira”. Anais do $5^{\circ}$ Encontro Nacional da Anpur. Belo Horizonte, Cedeplar, 1995.

FILHO, A. de S. M. et al. "O geoprocessamento na construção de um índice de qualidade de vida urbana”. $8^{\circ}$ Encontro Nacional da Anpur. Porto Alegre, mimeo., 1999.

FRIEDMANN, J. "Empowerment: uma política de desenvolvimento alternativo". Oeiras: Celta, 1996.

GOMES, P. C. da C. "O conceito de região e sua discussão." In: CASTRO, I. E. et al. Geografia: conceitos e temas. Rio de Janeiro: Bertrand Brasil, 1995.

GUEDES, C. A. M.; NATAL, J. L. A. "Reestruturação espacial e gestão territorial no Centro-Oeste do Brasil - o caso da Usina Hidrelétrica de Serra da Mesa, em Goiás". Anais do $7^{\circ}$ Encontro Nacional da Anpur. Recife, 1997.

HIC/FOCOC/Fórum Brasileiro de Reforma Urbana. Tratado sobre a questão urbana: por cidades, vilas e povoados, justos, democráticos e sustentáveis. Pólis, no 16, 1994, São Paulo.

KOHLSDORF, M. E.; ROMERO, M. B. "Variáveis de análise urbana incidentes no zoneamento ecológico-econômico". Anais do $7^{0}$ Encontro Nacional da Anpur. Recife, 1997.

LACORTE, A. C.; BARBOSA, N. P. "Contradições e limitações dos métodos de avaliação de impactos em grandes projetos: uma contribuição para o debate". Anais do $6^{\circ}$ Encontro Nacional da Anpur, Brasília, 1995.

MARQUES DA SILVA, R. C. "Urbanismo, meio ambiente e cidade: questóes da legislação urbana no Rio de Janeiro". $8^{\circ}$ Encontro Nacional da Anpur. Porto Alegre, mimeo., 1999. 
METZGER, P. "Contribution à une problématique de l'environnement urbain”. Cahiers Science Humaine, 1994.

MMA/PNUD - Parceria 21: IBAM/ISER Formulação e implementação de políticas públicas compatíveis com os princípios de desenvolvimento sustentável definidos na Agenda 21 - Cidades Sustentáveis da Agenda 21 Brasileira, mimeo., 1999.

MONTE-MÓR, R. "Urbanização extensiva e lógicas de povoamento: um olhar ambiental.” In: SANTOS, M. et al. (Org.). Território: globalização e fragmentação. São Paulo, Hucitec/ANPUR, 1996.

MONTE-MÓR, R. L.; COSTA, H. S.M. "Diversidade ambiental urbano-rural no contexto da grande indústria: saneamento e qualidade de vida”. Anais do 70 Encontro Nacional da Anpur. Recife, 1997.

MOTA SILVA, S. R.; SHIMBO, I. "A identificação de interfaces entre os conceitos de desenvolvimento sustentável e os assentamentos habitacionais urbanos". $8^{\circ}$ Encontro Nacional da Anpur. Porto Alegre, mimeo., 1999.

MOURA, R. et al. "Modelo Curitiba: os riscos de uma cidade insustentável". $8^{\circ}$ Encontro Nacional da Anpur. Porto Alegre, mimeo., 1999.

OLIVEIRA JR., A. de Energia e Amazônia: subsídios para um enfoque regional. Anais do $\sigma^{\circ}$ Encontro Nacional da Anpur. Brasília,1995.

PACHECO, R. S. "Atores, interesses e processo democrático: a gestão de um conflito ambiental". Anais do $5^{\circ}$ Encontro Nacional da Anpur. Belo Horizonte, Cedeplar, 1995.

PECCHIO, R. "Gestão ambiental nos estuários de Recife: preservação x ocupação". Anais do $5^{\circ}$ Encontro Nacional da Anpur. Belo Horizonte, Cedeplar, 1995.

PEREIRA COSTA, S. de A et al. "Globalização e desenvolvimento sustentável: qualidade de lugar, qualidade de excelência”. $8^{\circ}$ Encontro Nacional da Anpur. Porto Alegre, mimeo., 1999.

PL 5788/90 e seus apensos anteriores e posteriores - Estatuto da Cidade.

COMISSÃO DE DESENVOLVIMENTO URBANO E INTERIOR (Substitutivo ao Projeto de Lei no 5.788, de 1990 e seus apensos) Regulamenta o Capítulo da Política Urbana da Constituição Federal, estabelece diretrizes gerais da Política Urbana e dá outras providências.

REBORATTI, C. "La cuestión ambiental". IV Seminario Internacional de la Red Iberoamericana de Investigadores - Globalización y Territorio. Bogotá, abril de 1998.

RIBEIRO, E. R. et al. "Variáveis ambientais incidentes no processo de avaliação do impacto urbano: proposta metodológica para aplicação de matrizes". $8^{\circ}$ Encontro $\mathrm{Na}$ cional da Anpur. Porto Alegre, mimeo., 1999.

RODRIGUES, A. M. Produção e consumo no espaço - problemática ambiental urbana. São Paulo: Hucitec, 1998.

SANTOS, M. A natureza do espaço: razão e emoção. São Paulo: Hucitec, 1997.

SANTOS, M. A urbanização brasileira. São Paulo: Hucitec, 1994.

SÁ, S. et al. "Exclusão e risco ambiental: populações humanas, comunidade científica e aplicações do direito ambiental na Amazônia”. Anais do $\sigma^{\circ}$ Encontro Nacional da Anpur. Brasília, 1995.

SILVA, E. L. B da et al. "Planejamento urbano por análise de desempenho: impactos das atividades sobre o sistema viário". $8^{\circ}$ Encontro Nacional da Anpur. Porto Alegre, mimeo., 1999. 
SILVA, M. das G. "O papel das propostas educativas na conformação das práticas de apropriação do meio ambiente em área de Grande Projeto de Investimento (GPI): o caso de UHE-Tucuruí/PA". $8^{\circ}$ Encontro Nacional da Anpur. Porto Alegre, mimeo., 1999.

STEINBERGER, M. A relação meio ambiente-meio urbano: do global para o local. Anais do $6^{\circ}$ Encontro Nacional da Anpur. Brasília, 1995.

"Zoneamento ecológico-econômico como instrumento de ordenamento territorial urbano e regional". Anais do $7^{\circ}$ Encontro Nacional da Anpur. Recife, 1997.

TEIXEIRA, M. G.; BESSA, E. S. "A modernização industrial e a produção local: um estudo dos efeitos desiguais na Baía de Guanabara". Anais do $7^{\circ}$ Encontro Nacional da Anpur. Recife, 1997.

TOFANI, F. de P. "Por um modelo de desenvolvimento turístico sustentável para comunidades economicamente, socioculturalmente e ambientalmente frágeis". $7^{\circ}$ Encontro Nacional da Anpur. Porto Alegre, mimeo., 1999.

TOPALOV, C. "Do planejamento à ecologia: nascimento de um novo paradigma de ação sobre a cidade e o habitat?" Rio de Janeiro, Cadernos do IPPUR/UFRJ, ano 1, no 1, jan./abr., 1986.

TORRES, H. da G. et al. "Poluição hídrica, produção industrial e controle ambiental: o caso das siderúrgicas da bacia do Rio Piracicaba (MG)". Anais do $7^{\circ}$ Encontro Nacional da Anpur. Recife, 1997.

TRIMIÑO, G. J. C. "Pobación, geografia y economia: universidad, totalidad y ecointerdependencia". Havana, 1997.

VAINER, C. "Planejamento e questão ambiental: qual é o meio ambiente que queremos planejar". Anais do V Encontro Nacional da Anpur. Belo Horizonte, Cedeplar, 1995.

VARGAS, H. C. "Cubatão: do desenvolvimento regional ao local, passando pela questão ambiental". Anais do $6^{\circ}$ Encontro Nacional da Anpur. Brasília, 1995.

. "Qualidade ambiental urbana: em busca de uma nova ética". $8^{\circ}$ Encontro $\mathrm{Na}$ cional da Anpur. Porto Alegre, mimeo., 1999.

VERGARA, R. O. P. "A politização do meio ambiente: ONGs e a gestão ambiental no Recife". Anais do $6^{\circ}$ Encontro Nacional da Anpur. Brasília, 1995.

ULTRAMARINI, C.; PEREIRA, G. de F. "As práticas sociais e o desenvolvimento sustentável no meio urbano". $8^{\circ}$ Encontro Nacional da Anpur. Porto Alegre, mimeo., 1999.

A B S T R A C T The work is based on a study of knowledge concerning the environment, within the scope of the 1990s ANPUR Meetings, which discussed the emergence of the urban environment as a field of inquiry that constructs and reconstructs myths concerning the sustainability or unsustainability of urban space. To this end, the first section analyses documents which constitute the institutional imprint of the field, followed by a brief recollection of theoretical-conceptual landmarks established in some disciplines. It is suggested that these be deconstructed, so that the urban environment may be understood through a perspective based on a non-instrumental rationality. In the following section, the socio-historical and politicospatial focuses of three pairs of notions/concepts are discussed: ambient-environment, sustainable development-sustainability and territory-urbanization, in order to arrive at an understanding of urban sustainability. Such focuses guide the central issues that are related to the field: urban environmental quality, instruments of environmental management and the conflict of 
A ( R E ) C O N S T R U Ç $\tilde{A}$ O

interests among actors. In conclusion it is shown that, although most of the discourse on the urban environment considers urban space to be unsustainable, there are paths that point to a definition of the field.

K E Y W O R D S Environment; sustainability; urban space. 